\title{
Drainage, salt leaching and physico-chemical properties of irrigated man-made terrace soils in a mountain oasis of northern Oman
}

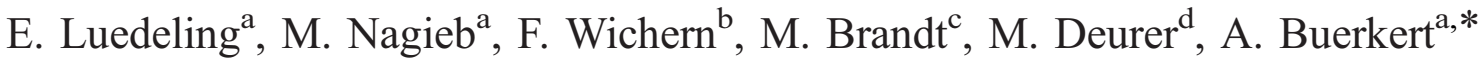 \\ anstitute of Crop Science, University of Kassel, D-37213 Witzenhausen, Germany \\ ${ }^{\mathrm{b}}$ Department of Soil Biology and Plant Nutrition, University of Kassel, D-37213 Witzenhausen, Germany \\ ${ }^{\mathrm{c}}$ Department of Soil Science, University of Kassel, D-37213 Witzenhausen, Germany \\ dinstitute of Soil Science, University of Hannover, Herrenhäuser Straße 2, D-30419 Hannover, Germany
}

Received 5 February 2004; received in revised form 12 August 2004; accepted 3 September 2004

Available online 18 October 2004

\begin{abstract}
Little is known about the sustainability of irrigated oasis agriculture in northern Oman. The objective of this study therefore was to examine which factors allowed agricultural productivity to be apparently maintained during the two millenia of a mountain oasis' existence. Soil moisture and physico-chemical properties were measured in a typical flood-irrigated field sown to alfalfa (Medicago sativa L.). Particle size, organic $\left(C_{\text {org }}\right)$ and inorganic carbon content, $\mathrm{pH}$ and electrical conductivity (EC) of the soil profile were analyzed at $0.15,0.45$ and $1.00 \mathrm{~m}$. Saturated hydraulic conductivity and the soil's apparent bulk density and water potential were determined from undisturbed samples at $0.05,0.25$ and $0.60 \mathrm{~m}$. During irrigation cycles of 6-9 days, volumetric water contents ranged from $30 \%$ to $13 \%$. A tracer experiment with potassium bromide revealed that $52-56 \%$ of the irrigation water was stored in the upper $0.4 \mathrm{~m}$ of the soil. The rest of the water moved further down the profile, thus providing the necessary drainage to avoid the build-up of toxic salt concentrations. Due to differences in pore size, plant-available water in the topsoil amounted to $18.7 \%$ compared to $13 \%$ and $13.5 \%$ at 0.25 - and $0.60-\mathrm{m}$ depth, respectively. The aggregate structure in the upper $1.0 \mathrm{~m}$ of the profile is likely preserved by concentrations of calcium carbonate $\left(\mathrm{CaCO}_{3}\right)$ from 379 to $434 \mathrm{mg} \mathrm{kg}^{-1}$ and $C_{\text {org }}$ from 157 to $368 \mathrm{mg} \mathrm{kg}^{-1}$ soil. The data indicate that the sustainability of this irrigated landuse system is due to high water quality with low sodium but high $\mathrm{CaCO}_{3}$ concentration, the elaborate terrace structure and water management which allows adequate drainage.
\end{abstract}

(C) 2004 Elsevier B.V. All rights reserved.

Keywords: Aflaj; Anthropogenic soil; Leaching; Hydraulic conductivity; Salinization

* Corresponding author. Fax: +49 5542981230.

E-mail address: buerkert@uni-kassel.de (A. Buerkert).

\section{Introduction}

In arid regions, agriculture is mainly limited by the availability of suitable irrigation water. However, even with sufficient water, its use is often not

0016-7061/\$ - see front matter (C) 2004 Elsevier B.V. All rights reserved. doi:10.1016/j.geoderma.2004.09.003 
sustainable, leading to soil salinization as a consequence of inappropriate irrigation and drainage techniques. Nevertheless, despite extremely xeric moisture regimes, some systems of intensive agriculture have been productive for millennia with only a moderate build-up of toxic salt levels (Nagieb et al., in press; Buerkert et al., 2005; Wichern et al., 2004b). The mechanisms that govern the sustainability of these systems, however, have not yet been sufficiently investigated.

A suitable location to study the effects of irrigation and the sustainability of dryland agriculture is the Sultanate of Oman on the Arabic peninsula. The country's climate is very arid and hot, with an average temperature of $27{ }^{\circ} \mathrm{C}$, peak temperatures of $45{ }^{\circ} \mathrm{C}$ in summer and a mean annual rainfall of $105 \mathrm{~mm}$, all measured in the capital Muscat (Dorvlo and Ampratwum, 1998, 1999). Over the years, precipitation shows a very erratic pattern in which relatively moist years of more than $300 \mathrm{~mm}$ alternate with dry years of less than $50 \mathrm{~mm}$ of annual rainfall (Norman et al., 1998; Victor and Al-Farsi, 2001). Droughts lasting as long as 5 years are also common. This climate makes only $0.3 \%$ of Oman's surface eligible for crop production (FAO, 1997), practically all of which is covered by two different types of intensive irrigation agriculture. About $74 \%$ of the total agricultural land is irrigated by sprinkler systems and large portions of it are facing serious problems of salinity and groundwater depletion after only a few decades of use. Most of these systems are located in the Batina region near the northeastern coast of the country (Victor and Al-Farsi, 2001).

In the mountainous regions of Northern Oman, a completely different form of agriculture has persisted for millennia (Nagieb et al., in press). Date palms and annual crops are cultivated in oases that are watered either by springs or by tunnel systems, called aflaj (sing. Falaj; Norman et al., 1998; Wilkinson, 1977) in Arabic, which were dug into the ground or carved into the rock to tap underground aquifers. Both systems require the oases to be located at the foot of cliffs, below plateaus, which accumulate the scarce rainfall of a large area. The accumulated water that resurfaces at the bottom of the cliffs becomes an important resource for irrigation. This geomorphological setting provides a reliable water supply necessary for intensive yearround date and crop cultivation on ancient, artificial terrace soils that are disconnected from the groundwater table and thus do not suffer from salinization due to capillary rise such as observed for nonterraced soils (Jorenush and Sepaskhah, 2003). Outside the terraces, a very rough landscape characterised by barren rock or unstructured dry sediments prevail.

In view of the above, the objective of this study was to examine how water quality and management, and profile structure of the man-made terraces allowed agricultural productivity and soil quality to be maintained during the more than two millennia of an oasis' existence.

\section{Materials and methods}

\subsection{Site description}

The study was conducted in the mountain oasis of Balad Seet $\left(23.19^{\circ} \mathrm{N}, 57.39^{\circ} \mathrm{E}, 995 \mathrm{~m}\right.$ asl $)$ in the Jabal Akhdar mountains of Oman (Fig. 1). The agriculture of the oasis consists of extensive date palm (Phoenix dactylifera L.) gardens and terraced fields, where annual and perennial crops such as landraces of wheat (Triticum spp. L.; Al-Maskri et al., 2003), barley (Hordeum vulgare L.), garlic (Allium sativum L.), onion (Allium cepa L.), coriander (Coriandrum sativum L.) and alfalfa (Medicago sativa L.) are cultivated. The irrigation water for the oasis' agriculture is distributed through an elaborate aini-aflaj canal system fed from 12 springs originating at the foot of a calcareous rock wall of $1000-\mathrm{m}$ height in the southwest of the settlement. The oasis is home to about 650 people, among whom 48 households cultivate the 13.1 ha of available agricultural land (Nagieb et al., in press).

Flood-irrigation of the terraces, which are divided into square plots (jalba in Arabic) of about $2 \mathrm{~m}^{2}$, occurs at intervals between 5 to 18 days, depending on the season. The soils of the terraces are classified as Irragric Anthrosols (FAO, 2001). There is considerable variation of profile depth which is $1.3 \mathrm{~m}$ in the examined part of the Mazra terrace system (Fig. 2). The lower $0.3 \mathrm{~m}$ of the soil 


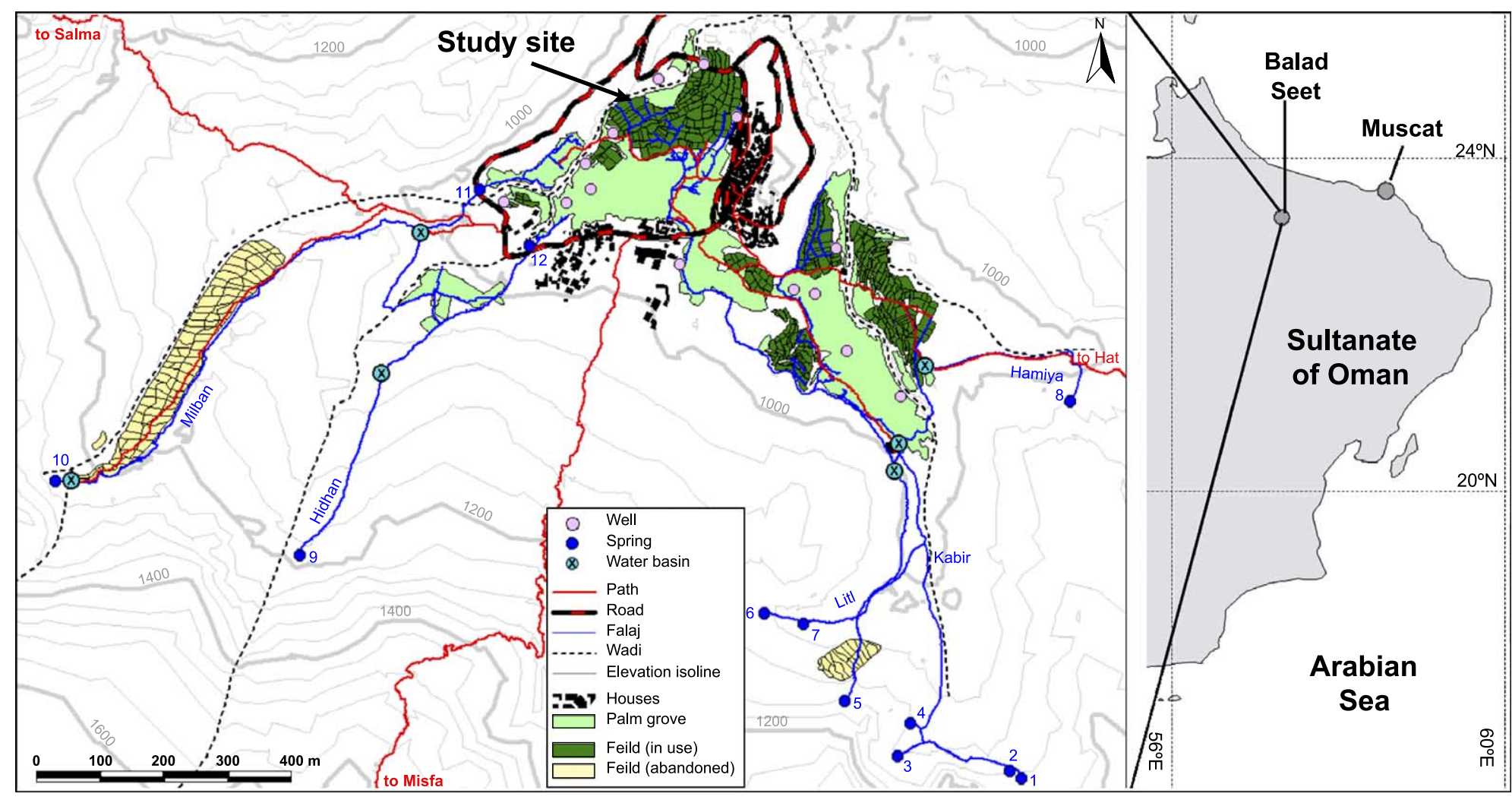

Fig. 1. Map of the Sultanate of Oman with the mountain oasis of Balad Seet inserted. The black arrow indicates the terraced field of alfalfa $(M$. sativa L.) where the study was conducted. 

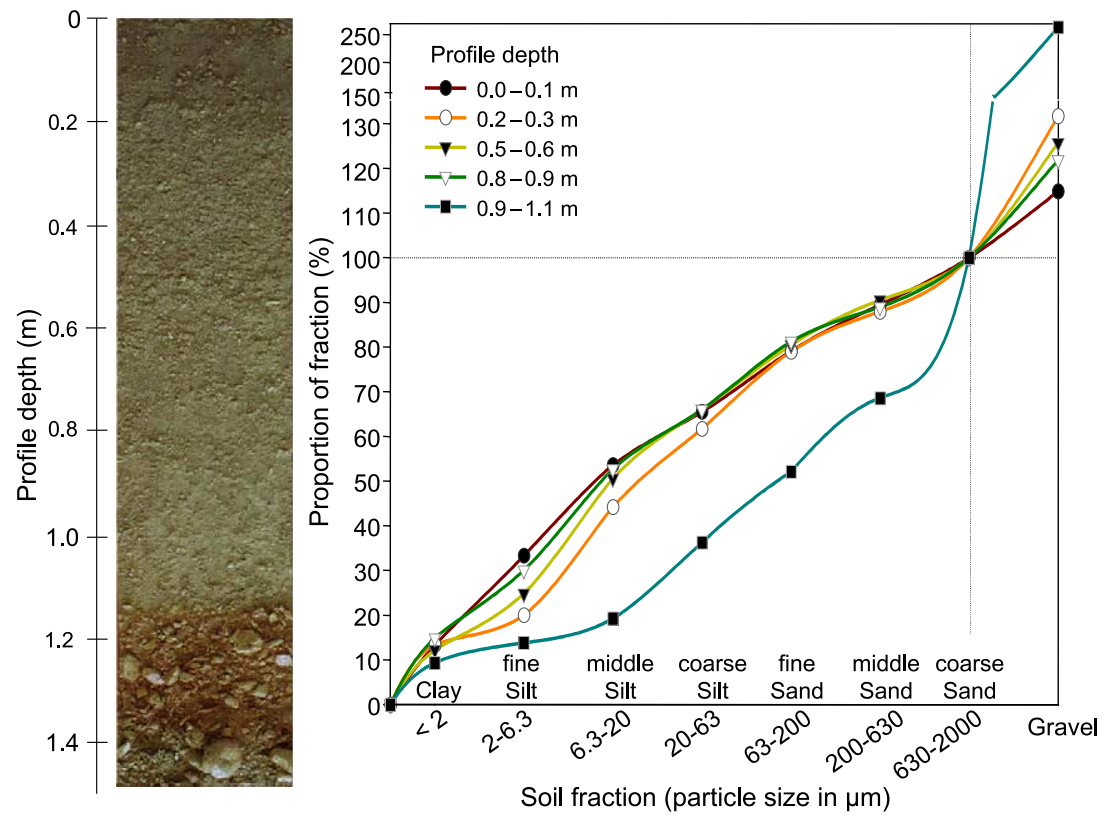

Fig. 2. Soil profile of the lower part of the Mazra terrace system at the mountain oasis Balad Seet (Oman) planted with annual crops and alfalfa. Note the difference between the gray, silt-rich upper layers of this man-made profile with their high water-holding capacity and the lower portion with its reddish, stony and rapidly draining structure (left) and the large difference in the particle size distribution curve below $0.9 \mathrm{~m}$ (right). The value of $100 \%$ refers to the mass of the mineral soil, the gravel fraction is not included in the mineral soil and thus leads to numbers exceeding $100 \%$.

profile of Mazra consists of two layers of gravel with different colours and stone sizes, on top of which $1.0 \mathrm{~m}$ of silt-rich material, was placed at the time of terrace construction. That time has been dated to $1092 \pm 43$ years using the ${ }^{14} \mathrm{C}$ method.

\subsection{Basic soil characteristics}

Organic $\left(C_{\text {org }}\right)$ and inorganic $\left(C_{\text {inorg }}\right)$ carbon concentrations $\left(C_{\text {inorg }}=\mathrm{C}_{\text {total }}-C_{\text {org }}\right)$ were determined in samples from three different depth intervals $(0-0.15$, $0.15-0.45,0.45-1.00 \mathrm{~m}$ ) of an irrigated plot cultivated with alfalfa (M. sativa L.) using a LECO-RC 412 C-Analyser (LECO, St. Joseph, MI, USA). The electrical conductivity of the samples $\left(\mathrm{EC}_{\mathrm{e}}\right)$ was analyzed in a saturated soil paste (United States Salinity Laboratory Staff, 1954) by extracting the water from the paste using a suction filter and measuring the EC with a LF 90 conductivity meter (WTW, Weilheim, Germany). Analysis in a saturated paste was preferred over a fixed soil/water ratio, as it relates more closely to plant growth (United States Salinity Laboratory Staff, 1954). The $\mathrm{pH}$ of the soil was determined in a 1:2 soil suspension with deionised water.

\subsection{Particle size distribution}

To determine the particle size of the soil, $25 \mathrm{ml}$ of sodiumpolyphosphate was added to $10 \mathrm{~g}$ of soil. The samples were shaken and treated with ultrasound for 5 min for complete dispersion. Calcium carbonate $\left(\mathrm{CaCO}_{3}\right)$ and organic matter were not destroyed as the $\mathrm{CaCO}_{3}$ fraction amounted to more than $35 \%$ of this soil (Wichern et al., 2004a). A particle size analysis with a large proportion of compound particles being destroyed would not allow any conclusion about its hydraulic properties (Lado et al., 2004). The sand and coarse silt fractions were determined by sieving and the finer fractions by the pipette method (Gee and Bauder, 1986).

\subsection{Soil moisture}

The volumetric water content $\left(\theta,\left[\mathrm{m}^{3} \mathrm{~m}^{-3}\right]\right)$ of the topsoil $(0-0.2 \mathrm{~m})$ was determined by continu- 
ously measuring the electrical conductivity (EC, $[\mathrm{S}$ $\left.\mathrm{m}^{-1}\right]$ ) of the soil using four 20-cm-long $\mathrm{ECH}_{2} \mathrm{O}$ dielectric capacitance probes (Decagon Devices, Pullman, Washington, USA). The voltage readings (in $\mathrm{mV}$ ) on the probes are based on the difference between the dielectric number $(\varepsilon)$ of the soil water $\left(\varepsilon=80\right.$ at $\left.20{ }^{\circ} \mathrm{C}\right)$, the soil matrix $(\varepsilon<10)$ and the soil air $(\varepsilon=1)$ (Fares and Alva, 2000). A close correlation between EC and soil water content has been described by several authors (Wu, 1998; Fares and Alva, 2000). An influence of irrigation water quality on probe readings was unlikely given its low salt concentration.

The readings of the $\mathrm{ECH}_{2} \mathrm{O}$ probes were collected in 30-min intervals and stored with a Campbell CR10 (Campbell Scientific, Logan, UT, USA) datalogger. To calibrate the measurements (Mead et al., 1995; Khosla and Persaud, 1997; Chanzy et al., 1998; Lane and Mackenzie, 2001), the volumetric water content of the soil was determined thermogravimetrically on nine occasions. Subsequently, a linear regression was estimated $\left(r^{2}=0.96\right)$ using the data obtained from the $\mathrm{ECH}_{2} \mathrm{O}$ probes and these volumetric measurements. As the readings for the individual probes varied considerably, each probe had to be calibrated separately. After initial experiments under controlled conditions, no temperature correction (Campbell,
2002) was applied to the readings obtained as such corrections rather aggravated than alleviated the slight irregularities in the measurements (Fig. 3). The exact cause for these irregularities is unknown, but they are likely to be caused by the temperature extremes on the site, which lead to enhanced water vapour production in the soil. This vapour may have interacted with the salts in the profile. This phenomenon, however, was of minor importance compared to the overall moisture fluctuations during an irrigation cycle and will not be further discussed.

\subsection{Saturated hydraulic conductivity}

The saturated hydraulic conductivity $\left(k_{\mathrm{f}}\right)$ of the soil was determined using a hood permeameter as described by Hartge (1966). Five undisturbed soil samples were vertically excavated with $250-\mathrm{cm}^{3}$ cylinders at each of three depths $(0.00-0.06,0.20$ 0.25 and $0.55-0.60 \mathrm{~m}$ ). This sampling occurred at a $<5$-m distance of the plot where the tracer experiment was conducted. The cylinders were sealed with a lid and tape and transported to Germany, where the soil was carefully saturated with water. This was achieved by placing the cylinders on a layer of rough wire netting in a tub and then slowly raising the water level above the top of the cylinders. The

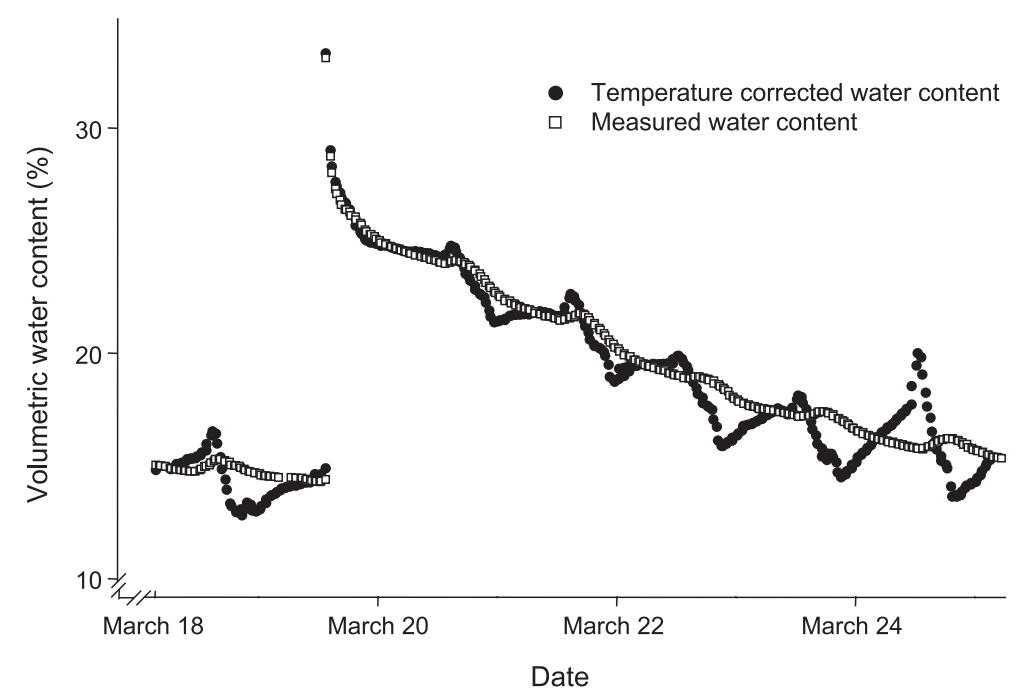

Fig. 3. Soil water dynamics during 7 days in an alfalfa-planted field at the mountain oasis Balad Seet (Oman) in March 2002 with and without the temperature correction for the volumetric water content $(\theta)$ as provided by the probe manufacturer. 
permeameter was then connected to the top of the cylinders and water was added to the top of the permeameter to create excess pressure on the soil surface. The amount of water percolating through the profile was measured and the $k_{\mathrm{f}}$ determined by the Darcy equation.

\subsection{Soil water potential}

To determine a typical water characteristic function for the terrace soil, five undisturbed samples were taken in $100-\mathrm{cm}^{3}$ volumetric cylinders from the same depths of the same plot as the $k_{\mathrm{f}}$ samples. Sampling occurred vertically (instead of horizontally) to better represent the pore system relevant for drainage. The samples were analyzed using 5 and 15 bar pressure plate extractors (Soil Moisture Equipment, Santa Barbara, CA, USA). The soil in the cylinders was first slowly saturated with water from the bottom and placed on a porous, water-saturated ceramic plate in a pressure chamber. Then different levels of excess pressure corresponding to different soil water potentials were applied to the extractor and the water quantity draining from the samples at the specific pressures was determined. From these data, the overall pore volume was computed and the bulk density determined after drying of the samples.

\subsection{Vertical water movement}

To obtain information about the vertical movement of water in the soil profile, $10 \mathrm{~g}$ of potassium bromide $(\mathrm{KBr})$, corresponding to $6.7 \mathrm{~g}$ of bromide ions, was dissolved in $40 \mathrm{~L}$, respectively, $60 \mathrm{~L}$, of irrigation water and applied to two nearby $1 \times 1 \mathrm{~m}$ fallow plots (thereafter denoted as variant $\mathrm{Br}_{40}$, and $\mathrm{Br}_{60}$, respectively). These volumes and the flooding of the plot were similar to typical irrigation practices on this soil. The plots were then covered with plastic sheets to prevent evaporation. Thirteen days after tracer application, soil samples were taken in triplicate from each of the plots at four different depth intervals $(0-0.20,0.20-0.40,0.40-0.60$ and $0.60-0.80 \mathrm{~m})$. Bromide was analyzed according to Flury (1993), where $40 \mathrm{ml}$ of deionised water was added as an extraction agent to $20 \mathrm{~g}$ of soil. After shaking for $30 \mathrm{~min}$, the mixture was centrifuged and microfiltrated. Subsequently, the $\mathrm{Br}^{-}$concentration in the extract was measured with a DIONEX ICS-90 ion chromatograph (Dionex, Sunnyvale, CA, USA). From the average of the diluted and undiluted extracts, blind values from samples of an adjacent plot where no $\mathrm{Br}^{-}$had been applied were subtracted to account for the natural background of $\mathrm{Br}^{-}$in the soil. From the bulk density at the different soil depths, the soil mass of the layers and the total amount of $\mathrm{Br}^{-}$contained therein were calculated. For this the bulk densities were corrected for the gravel content of the samples, as gravel cannot store water. Correlating these data with the $\mathrm{Br}^{-}$concentration in the irrigation water allowed the amount of water stored in the soil at different depths to be estimated as well as the amount of water leached beyond $0.80 \mathrm{~m}$. This correlation is expected to be realistic as bromide is known to behave conservatively in most soils (Brooks et al., 1998) with anion exclusion and other transport retardation or acceleration factors playing only minor roles (Porro et al., 1993). Given the physical structure of the profile, this latter portion of water was considered to be draining to the aquifer.

\subsection{Quality of irrigation water}

Spring water samples were taken from the main aflaj of the oasis. As all springs originate from only one aquifer, unfiltered samples were pooled, placed in a PE bottle, transported frozen to Germany and analyzed according to standard German DIN methods at SEWA (Essen) as follows: an ICP-AES was used for $\mathrm{Mg}, \mathrm{Ca}, \mathrm{Na}$ and $\mathrm{K}$; $\mathrm{Cl}$ was analyzed by titration and $\mathrm{SO}_{4}, \mathrm{HCO}_{3}$ and $\mathrm{CO}_{3}$ by ion chromatography. Electrical conductivity was measured conductometrically and $\mathrm{pH}$ potentiometrically.

The sodium adsorption ration (SAR) which indicates the effect of relative cation concentration on sodium accumulation in the soil was calculated as follows whereby ions are expressed as milliequivalents per liter (meq $\left.\mathrm{L}^{-1}\right)$.

$S A R=\frac{N a}{\sqrt{\frac{C a+M g}{2}}}$

Residual sodium carbonate was calculated as $\left[\mathrm{RSC}=\left(\mathrm{CO}_{3}+\mathrm{HCO}_{3}\right)-(\mathrm{Ca}+\mathrm{Mg})\right]$. 


\subsection{Calculation of leaching fractions and leaching requirements}

The leaching fraction establishes a relation between drainage and salinity. It may be estimated from a steady-state salt-balance equation (Hoffman and Durnford, 1999) as:

$L f=\frac{D_{\mathrm{d}}}{D_{\mathrm{a}}}=\frac{E C_{\mathrm{w}}}{E C_{\mathrm{d}}}$,

where $D_{\mathrm{d}}[\mathrm{mm}]$ is the amount of drainage water from the root zone, $D_{\mathrm{a}}[\mathrm{mm}]$ is the amount of irrigated water, $\mathrm{EC}_{\mathrm{w}}[\mathrm{dS} / \mathrm{m}]$ is the electrical conductivity of the irrigation water and $\mathrm{EC}_{\mathrm{d}}[\mathrm{dS} / \mathrm{m}]$ is the electrical conductivity of the water draining from the root zone. It is difficult to measure $\mathrm{EC}_{\mathrm{d}}$ in situ. Therefore we estimated $\mathrm{EC}_{\mathrm{d}}$ as recommended by Ayers and Westcot (1994) as $2 \mathrm{EC}_{\mathrm{e}}$, where $\mathrm{EC}_{\mathrm{e}}[\mathrm{dS} / \mathrm{m}]$ is the average soil salinity measured in a saturation extract.

The leaching requirement ( $\mathrm{Lr}$ ) is the amount of additional irrigation water required to avoid a harmful built-up of salts in the root zone of plants. This amount depends on numerous factors, including the salinity of the soil, soil type, water quality, rainfall, drainage, and crop tolerance. Probably the single most important factor is the quality of the water. The water quality sets the lower limit for the minimum salinity that can accommodate the growth of a specific crop (such as alfalfa). The leaching requirement for a specific crop can be estimated with different methods, one of which is given by Ayers and Westcot (1994) as:

$L r=\frac{E C_{\mathrm{w}}}{\left[5 E C_{\mathrm{e}, \mathrm{C}}-E C_{\mathrm{w}}\right]}$,

where $\mathrm{EC}_{\mathrm{e}, \mathrm{C}}[\mathrm{dS} / \mathrm{m}]$ is the average soil salinity measured in a saturation extract tolerated by a specific crop C. For alfalfa, no yield reduction is expected for $\mathrm{EC}_{\mathrm{e}}<2.0$ (Ayers and Westcot, 1994).

\subsection{Statistics}

One-way analyses of variance of all data were carried out using Statview 5.0 (SAS Inst., Cary, NC, USA) and Fisher's protected least significant difference (LSD) test was used to separate means.

\section{Results}

\subsection{Basic soil characteristics}

The $C_{\text {inorg }}$ concentration exceeded $4 \%$ at all depths. These high values reflect the lime content of up to $43 \%$ throughout the profile (Table 1). Alkaline soil conditions are reflected in $\mathrm{pH}$ values ranging between 8.3 and 8.4. However, this alkalinity is not the result of increased salinization (see below). Organic carbon was $3.7 \%$ in the topsoil, but declined substantially with depth. The soil's electrical conductivity (EC) was moderately high in the upper 0.45 $\mathrm{m}$ of the soil but four to five times higher below 0.45 $\mathrm{m}$ (Table 1).

\subsection{Particle size}

The soil profile can be stratified into two layers. The upper grayish coloured part $(0-0.9 \mathrm{~m})$ has a homogeneous particle size distribution with about $14 \%$ clay, $51 \%$ silt, $35 \%$ sand, and an additional $24 \%$ gravel, relative to the fine mineral soil. The lower layer $(0.90-1.10 \mathrm{~m})$, in contrast, showed a much higher proportion of coarse material with only $9 \%$ clay and $27 \%$ silt, but $64 \%$ sand and a very high gravel content that amounted to $163 \%$ of the mass of mineral soil. Comparisons of the profile's colours with material from the surrounding mountains indicate that the upper layers likely are sediment deposits collected from the floor of the valley (wadi) after heavy rainfall events, while the lower layers, particularly the reddish subsoil material (>1.10 m; Fig. 2) come from broken bedrock material.

Table 1

$\mathrm{pH}$ and concentration of inorganic carbon $\left(C_{\text {inorg }}\right), \mathrm{CaCO}_{3}$, organic carbon $\left(C_{\text {org }}\right)$, electrical conductivity of the soil $\left(\mathrm{EC}_{\mathrm{e}}\right)$ and leaching fraction $(\mathrm{Lf})$ at three different depths of a terrace soil from Balad Seet (Oman)

\begin{tabular}{lllllll}
\hline Depth (m) & $\mathrm{pH}$ & $\begin{array}{l}C_{\text {inorg }} \\
(\%)\end{array}$ & $\begin{array}{l}\mathrm{CaCO}_{3} \\
(\%)\end{array}$ & $\begin{array}{l}C_{\text {org }} \\
(\%)\end{array}$ & $\begin{array}{l}\mathrm{EC}_{\mathrm{e}} \\
\left(\mathrm{dS} \mathrm{m}^{-1}\right)\end{array}$ & $\mathrm{Lf}^{\mathrm{a}}$ \\
\hline $0.00-0.15$ & 8.3 & 4.6 & 37.9 & 3.7 & 1.40 & 0.18 \\
$0.15-0.45$ & 8.4 & 4.7 & 38.9 & 3.0 & 0.88 & 0.28 \\
$0.45-1.00$ & 8.4 & 5.2 & 43.4 & 1.6 & 4.83 & 0.05 \\
\hline
\end{tabular}

${ }^{a}$ Estimated according to Ayers and Westcot (1994) as $\mathrm{EC}_{\mathrm{w}} /$ $\left(2 \mathrm{EC}_{\mathrm{e}}\right)$ 


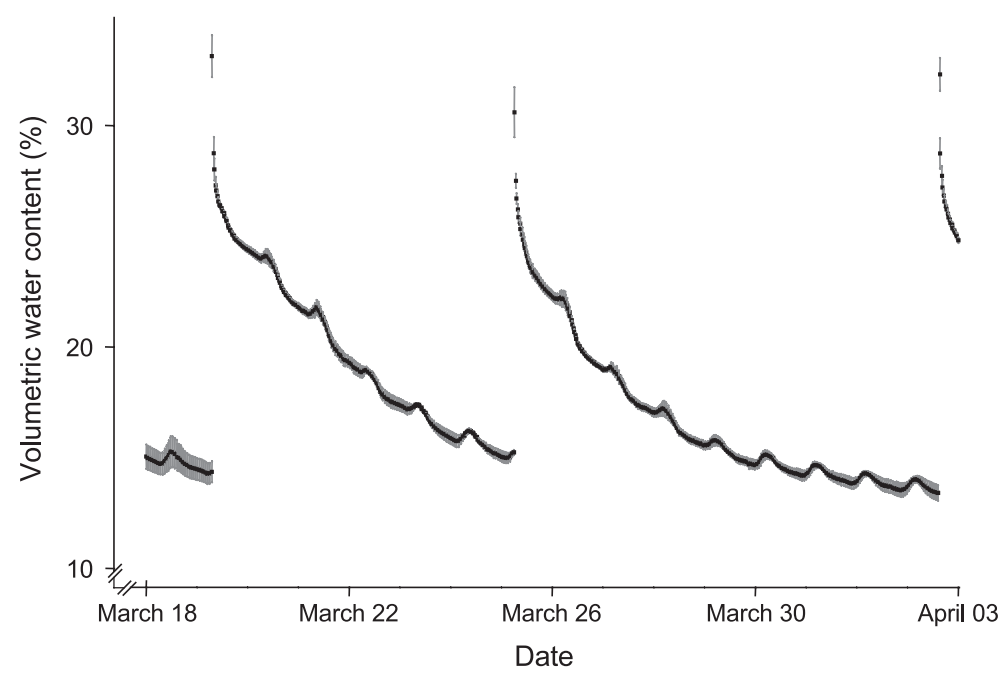

Fig. 4. Soil water dynamics during two irrigation cycles in an alfalfa-planted field at the mountain oasis Balad Seet (Oman) in March and April 2002. The data are means of four probes with the grey bars indicating \pm one standard error.

\subsection{Soil moisture}

In each of two selected irrigation cycles between March 18th and April 3rd 2002, an initial rise of the volumetric water content to between $30.6 \%$ and $33.1 \%$ was recorded in the topsoil, with a subsequent decline in soil moisture to between $13.4 \%$ and $15.0 \%$ (Fig. 4). Cycle durations lasted 5 days, $21 \mathrm{~h}$ and 8 days, $14 \frac{1}{2} \mathrm{~h}$, respectively. For the rest of the year 2002, the irrigation cycles varied between 5 and 18 days, with cycle duration decreasing during the hot summer months when the plant water demand was higher. The probes indicated a slight rise in soil water content around noon of each day (Fig. 4).

Table 2

Saturated hydraulic conductivity, total pore volume, bulk density and available field capacity ( \pm one standard error of the mean) of undisturbed soil samples from a terrace plot at Balad Seet

\begin{tabular}{lllll}
\hline $\begin{array}{l}\text { Depth } \\
(\mathrm{m})\end{array}$ & $\begin{array}{l}\text { Saturated } \\
\text { hydraulic } \\
\text { conductivity } \\
\left(k_{\mathrm{f}}\right)\left(\mathrm{m} \mathrm{day}^{-1}\right)\end{array}$ & $\begin{array}{l}\text { Total pore } \\
\text { volume } \\
(\%)\end{array}$ & $\begin{array}{l}\text { Bulk density } \\
\left(\mathrm{kg} \mathrm{m}^{-3}\right)\end{array}$ & $\begin{array}{l}\text { Available } \\
\text { field } \\
\text { capacity } \\
\left(\mathrm{m}^{3} \mathrm{~m}^{-3}\right)\end{array}$ \\
\hline $0.00-0.06$ & $2.76 \pm 0.4 \mathrm{a}$ & $61.6 \pm 0.3 \mathrm{a}$ & $1020 \pm 10 \mathrm{a}$ & $0.187 \pm 0.02 \mathrm{a}$ \\
$0.20-0.25$ & $8.40 \pm 0.7 \mathrm{~b}$ & $56.9 \pm 0.5 \mathrm{~b}$ & $1140 \pm 10 \mathrm{~b}$ & $0.130 \pm 0.01 \mathrm{~b}$ \\
$0.55-0.60$ & $6.81 \pm 0.8 \mathrm{~b}$ & $56.7 \pm 0.6 \mathrm{~b}$ & $1150 \pm 20 \mathrm{~b}$ & $0.135 \pm 0.01 \mathrm{~b}$ \\
\hline
\end{tabular}

a Amount of water a soil is able to retain against gravity (field capacity, FK) minus the amount of water which is retained by soil water tension $(>\mathrm{p} F \quad 4.2$; still water) and therefore not usable for agricultural crops. Values within one variable with the same letter do not differ at $p<0.05$. Data are means of four replicates.

\subsection{Saturated hydraulic conductivity $\left(k_{f}\right)$}

Of the five samples for each depth, typically one had a conductivity that was several-fold higher than that of the other samples from that layer. After conducting an outlier test (Dixon, 1950), these samples, which might not have been properly filled on site and therefore been disturbed during their transport on the bumpy mountain access road, were

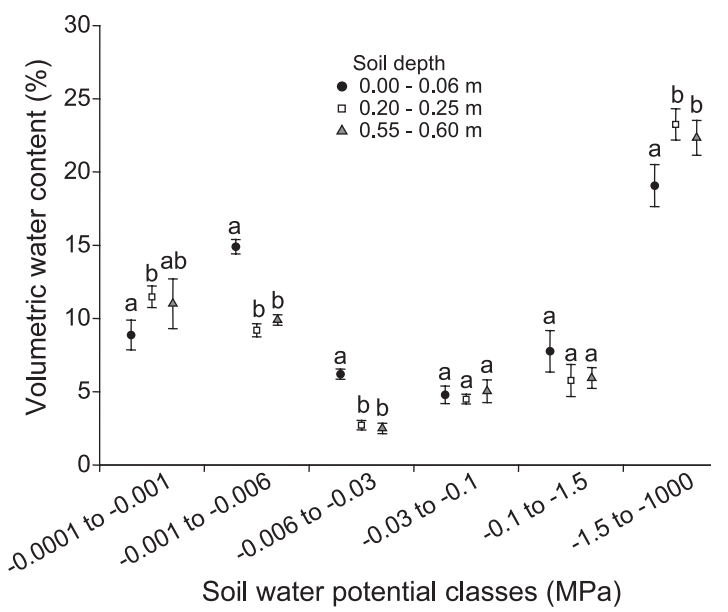

Fig. 5. Pore volume at different depths and soil water potential classes of a terrace soil at the mountain oasis of Balad Seet, Oman. Vertical bars indicate \pm one standard error. Values at the same soil water potential with the same letter are not significantly different at $p<0.05$. 


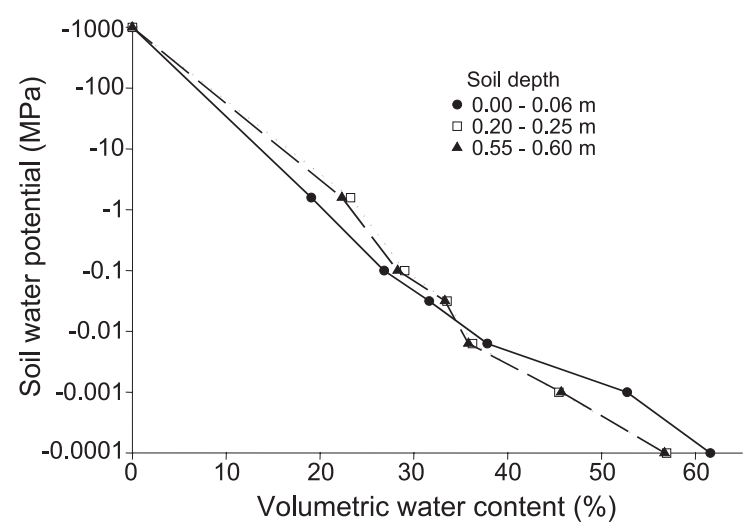

Fig. 6. Soil water characteristic function showing water contents at different soil water potentials for three depths of a terrace soil at the mountain oasis of Balad Seet, Oman. Vertical bars indicate \pm one standard error.

discarded. The four replicates used for comparison consistently showed a high saturated hydraulic conductivity. Nevertheless, the hydraulic conductivity $\left(k_{\mathrm{f}}\right)$ in the subsoil was with $840 \pm 69$ and $681 \pm 83 \mathrm{~cm}$ day $^{-1}$ much higher than in the topsoil $(276 \pm 41 \mathrm{~cm}$ day $^{-1}$ ) (Table 2). The greater total pore volume in the topsoil reflected its lower bulk density (Fig. 5).

\subsection{Soil water potential}

The fractions of soil macropores (defined by a soil water potential of -0.0001 to $-0.001 \mathrm{MPa}$ ) and of water not available for plants (defined by a soil water potential of -1.5 to $-1000 \mathrm{MPa}$ ) were higher at lower depths. The water characteristic function of the topsoil, however, showed a significantly higher fraction at a potential from -0.001 to $-0.03 \mathrm{MPa}$. This is the pressure range from which water can be extracted easily by plants. The equivalent pore volume at potentials between -0.03 and $-1.5 \mathrm{MPa}$ was relatively low and did not differ between the individual soil depths $(p<0.05)$. The soil water characteristic curve clearly shows the higher proportion of intermediate-size pores in the topsoil and the predominance of smaller pores at $0.20-0.25$ and $0.55-$ $0.60 \mathrm{~m}$ (Fig. 6).

\subsection{Vertical water movement}

The tracer experiment reveals that most of the applied water does not leave the topsoil of the profile, but remains in the upper $0.2 \mathrm{~m}$ of the soil (Table 3), where in both variants, the centre of mass of the $\mathrm{Br}^{-}$ concentration versus depth distribution is found. With increasing depth, the $\mathrm{Br}^{-}$concentration rapidly declines. In the topsoil, the $\mathrm{Br}^{-}$peak tends to be higher with the lower amount of applied water in variant $\mathrm{Br}_{40}$ than in $\mathrm{Br}_{60}$, whereas the reverse occurs at deeper layers. However, these differences are significant only at $0.20-0.40 \mathrm{~m}$.

The amount of water stored in the different layers also is affected by the amount of applied water (Table $3)$. Irrespective of depth, significantly more water is

Table 3

Bromide $\left(\mathrm{Br}^{-}\right)$concentrations and mass balance $\left(\%\right.$ of applied $\mathrm{Br}^{-}$recovered) in the soil after irrigation with 40 and $60 \mathrm{~L} \mathrm{~m}^{-2}\left(\mathrm{Br}_{40}\right.$ and $\mathrm{Br}_{60}$, respectively, containing 0.17 and $0.11 \mathrm{~g} \mathrm{Br} \mathrm{L}^{-1}$ ) of water in a tracer experiment conducted at Balad Seet (Oman) and estimated amounts of stored water at different soil depths

\begin{tabular}{|c|c|c|c|c|c|c|}
\hline Irrigation & $\begin{array}{l}\text { Soil depth } \\
(\mathrm{m})\end{array}$ & $\begin{array}{l}\text { Gravel corrected bulk } \\
\text { density }\left(\mathrm{kg} \mathrm{m}^{-3}\right)\end{array}$ & $\begin{array}{l}\text { Soil mass } \\
(\mathrm{kg})\end{array}$ & $\begin{array}{l}\mathrm{Br}^{-} \text {concentration } \\
\left(\mathrm{mg} \mathrm{kg}^{-1} \text { soil) }\right.\end{array}$ & $\begin{array}{l}\text { Total } \mathrm{Br}^{-} \\
\text {in soil }(\mathrm{g})\end{array}$ & $\begin{array}{l}\text { Stored water } \\
\text { (L) }\end{array}$ \\
\hline \multirow[t]{6}{*}{$\mathrm{Br}_{40}$} & $0.00-0.20$ & 940 & 188 & $17.2 \pm 0.2$ & $3.2 \pm 0.1$ & $19.2 \pm 0.4$ \\
\hline & $0.20-0.40$ & 880 & 175 & $1.5 \pm 0.3$ & $0.3 \pm 0.0$ & $1.6 \pm 0.1$ \\
\hline & $0.40-0.60$ & 1010 & 202 & $1.0 \pm 0.2$ & $0.2 \pm 0.0$ & $1.2 \pm 0.2$ \\
\hline & $0.60-0.80$ & 940 & 189 & $0.9 \pm 0.2$ & $0.2 \pm 0.1$ & $1.0 \pm 0.3$ \\
\hline & Sum & & & & $3.9 \pm 0.2$ & $23.0 \pm 1.1$ \\
\hline & $\%$ of applied & & & & 57 & \\
\hline \multirow[t]{6}{*}{$\mathrm{Br}_{60}$} & $0.00-0.20$ & 940 & 216 & $16.1 \pm 0.7$ & $3.0 \pm 0.2$ & $27.0 \pm 1.8$ \\
\hline & $0.20-0.40$ & 880 & 228 & $4.5 \pm 0.6$ & $0.8 \pm 0.2$ & $7.0 \pm 1.8$ \\
\hline & $0.40-0.60$ & 1010 & 230 & $1.9 \pm 0.2$ & $0.4 \pm 0.1$ & $3.4 \pm 0.5$ \\
\hline & $0.60-0.80$ & 940 & 230 & $1.5 \pm 0.1$ & $0.3 \pm 0.0$ & $2.5 \pm 0.1$ \\
\hline & Sum & & & & $4.5 \pm 0.5$ & $39.9 \pm 4.2$ \\
\hline & $\%$ of applied & & & & 67 & \\
\hline
\end{tabular}

Data are means of four replicates and wherever applicable followed by \pm one standard error of the mean. 
stored with $\mathrm{Br}_{60}$ than with $\mathrm{Br}_{40}$. However, as calculated from the amount of $\mathrm{Br}^{-}$applied but not accounted for in the analysis, there were only minor treatment effects on the amounts of drainage to deeper layers $\left(\mathrm{Br}_{40}=17.0 \pm 1.1 \mathrm{~L} ; \mathrm{Br}_{60}=20.1 \pm 4.2 \mathrm{~L}\right)$. Based on the mass balance calculations for $\mathrm{Br}^{-}$, the total amount of leaching beyond $0.8 \mathrm{~m}$ was estimated at $43 \%$ for $40-\mathrm{mm}$ irrigation $\left(\mathrm{Br}_{40}\right)$ and at $33 \%$ for 60 $\mathrm{mm}\left(\mathrm{Br}_{60}\right.$, Table 3$)$. Consequently, $57 \%$ or $67 \%$ of the applied water was stored in the well rooted upper soil layers.

\subsection{Quality of irrigation water and leaching requirement}

The analysis of the irrigation water revealed that the water was moderately hard with a sum of alkaline earth ions (total hardness) of $2.57 \mathrm{mmol} \mathrm{L}^{-1}$. Most of this hardness is caused by carbonate ions. The chloride $\left(\mathrm{Cl}^{-}\right)$concentration was low, the SAR much below critical levels for Na hazards and RSC negative (Table 4). Given the high quality of the irrigation water the leaching fraction for alfalfa with $\mathrm{EC}_{\mathrm{w}}=0.5$ and $\mathrm{EC}_{\mathrm{e}, \mathrm{C}}=2.0$ for a $100 \%$ crop yield is 0.05 (Table 1 ).

\section{Discussion}

The maintenance of the soil's salt concentration at a level which is not hampering the growth of even salt sensitive plants such as alfalfa by little, but regular, drainage is the main parameter which under the prevailing arid conditions determines the oasis' sustained productivity over time. Neither the measured $\mathrm{pH}$ levels of 8.3 to 8.4 nor the EC values of 0.88 to $1.40 \mathrm{dS} \mathrm{m} \mathrm{m}^{-1}$ show the effects of salt accumulation in the upper soil layers where most of the roots are observed. A major reason for the avoidance of salinization in the upper soil layers certainly is the quality of the spring irrigation water, with its high concentrations of hardly soluble carbonates and high $\mathrm{HCO}_{3}$ versus low $\mathrm{Na}$ and $\mathrm{Cl}$. According to the classification proposed by Rhoades et al. (1992), the irrigation water at Balad Seet has drinking water quality. It appears that most of its alkalinity is buffered by $\mathrm{Ca}$ and $\mathrm{Mg}$ leading to large precipitations of those minerals. This would explain the high $\mathrm{CaCO}_{3}$-concentrations throughout the pro- 
file (Table 1) and also leads to a low risk of alkalinisation or sodification.

The availability of high quality irrigation water and sufficient leaching within the traditional management system of this mountain oasis is also reflected in the low EC of the soil saturation extract. Even sensitive crops such as maize and alfalfa experience major yield declines only at between 1.7 and $5.9 \mathrm{dS} \mathrm{m}^{-1}$ and between 2.0 and $8.9 \mathrm{dS} \mathrm{m}^{-1}$ (Maas and Hoffmann, 1977; Rhoades, 1982).

This irrigation water quality also leads to small leaching requirements, such as 0.05 for alfalfa. Therefore, even with limited water resources, the main strategy to avoid salinization in the soils of the oasis seems to have been to establish leaching fractions in the root zone that are considerably higher than the leaching requirement (Table 1$)$. In the main rooting zone $(0-$ $0.45-\mathrm{m}$ depth), the salinity is well below the value $\left(\mathrm{EC}_{\mathrm{e}}=2.0\right)$ that would reduce the alfalfa yield. Only from the bottom of the root zone $(0.45 \mathrm{~m})$ downward a small build-up of salinity was observed (Table 1 ). The reason for this likely is the intensive extraction of water by the roots in the topsoil increasing the salinity of the residual water that leaches further downwards.

The mass of $\mathrm{Br}$ lost from the profile in $0-0.8 \mathrm{~m}$ (see Table 3) represents the leaching fractions for two typical irrigation cycles. It was 0.43 for $\mathrm{Br}_{40}$ and 0.33 for $\mathrm{Br}_{60}$. A smaller amount of irrigation at this site seems to be less effective (more Br lost) and leads to higher leaching fractions. Generally, the variation of the leaching fraction between individual irrigation cycles is high. Still the value of 0.33 is fairly close to the long-term leaching fraction of 0.16 that can be calculated by integrating the depth dependent leaching fractions (Table 1) over the depth of the tracer balance $(0-0.8 \mathrm{~m})$.

The available field capacity is particularly high in the topsoil (19\%), which likely reflects the effects of regular soil tillage and of abundant root growth. It also indicates that the topsoil has a significantly higher ability to store plant-available water than the deeper layers (Table 2). In the untilled subsoil, in contrast, the available field capacity is only moderately high $(13 \%)$. The necessary drainage of the soil is provided by the large proportion of macro-pores (at a soil water potential of $>-0.006 \mathrm{MPa}$ ) in the unploughed lower soil layers of $20.7 \%$ and $20.9 \%$ at 0.20 - and $0.55-\mathrm{m}$ depth, respectively, and among these especially by the large proportion of quickly draining pores (soil water potential of $>-0.001 \mathrm{MPa}$ ) of $11.5 \%$ and $11.0 \%$. During irrigation events, the significantly lower saturated water conductivity in the topsoil prevents a rapid leaching of water to deeper soil layers, thereby increasing the time available for infiltration into the smaller soil pores. After flooding, the macro-pores are rapidly drained, avoiding harmful effects of waterlogging on crop growth. The small amount of leached water (estimated in this study to be about 17 to $20 \mathrm{~L} \mathrm{~m}^{-2}$ ) is sufficient to transport salts to greater depths. However, the subsoil peak in the EC of $4.8 \mathrm{dS} \mathrm{m}^{-1}$ suggests that some solutes do not reach the gravely drainage layer at the bottom, but remain in the profile.

The very high $C_{\text {org }}$ concentrations in the oasis soil investigated are a third important prerequisite for the oasis' sustainability, as they contribute to aggregate stability, reduce the effects of salinization on plant growth by providing active cation and anion exchange sites, and supply plant nutrients by a high turnover rate (Wichern et al., 2004a). The high $C_{\text {org }}$ levels reflect the regular application of manure at rates of up to 20 tons $\mathrm{ha}^{-1}$ year $^{-1}$. A decrease in manure application and partial replenishment of extracted nutrients by mineral fertilizers, as observed in recent years in some plots of the oasis' terrace systems, may lead to a long-term decline of soil $C_{\text {org. }}$ In the longterm, increasing levels of salts in the soil profile may be the consequence of a deteriorating soil structure and hampered drainage.

The moisture dynamics of the soil profile describe the efficacy of the elaborate distribution system for the springs' outflow. The scarcity of water may motivate farmers to optimize its availability with crop evapotranspiration throughout the year. Lacking symptoms of water stress indicates that within an irrigation cycle the minimum topsoil moisture content of $13.4 \%$ is sufficient for maintaining crop metabolisms, even though according to the soil water curve, all water at that level should be non-available to plants. It must be assumed that during the latter part of the irrigation cycle, plants extract less water from the topsoil, in which the probes were installed, than from the rooted soil below, which extends to approximately $0.5 \mathrm{~m}$ depth. This layer is not exposed to solar radiation and consequently does not dry out rapidly. 
The daily rise in the moisture level at noon (Fig. 3) is an unexpected result and may reflect an experimental artefact. One explanation for this phenomenon could be the penetration of warm midday air into the soil and subsequent condensation around the impermeable plastic probes, thereby leading to erroneous increases in their soil moisture readings. However, this could not be verified experimentally.

\section{Conclusions}

High quality irrigation water, the elaborately built soil structure of the terraces, a system of water distribution designed to match crop needs during their different growth stages and adequate drainage are the main factors explaining the lack of salinization in ancient mountain oases of Oman. It remains to be seen, however, whether these aflaj-based systems can withstand the challenges posed by overpopulation, rapidly rising labour costs and the heavy use of mineral fertilizers instead of manure-based recycling to maintain their productivity. Given the aridity of the climate and high ambient temperatures, maintaining soil $C_{\text {org }}$ levels and appropriate leaching will certainly remain a key prerequisite to avoid the build-up of salts over time.

\section{Acknowledgements}

The authors are grateful to $\mathrm{H}$. Wildhagen, J. Böttcher and S. Siebert for their advice, to E. Wiegard, C. Thieme, B. Heiligtag, U. Pieper, M. Hammer-Weiß, and R. Spinger for their contributions to the soil analyses and to Horst Weier for the hydrogeological classification of the study area. They are also indebted to Sultan Qaboos University, Muscat for technical and logistical assistance and to the Deutsche Forschungsgemeinschaft (DFG) for funding. Many thanks also to the farmers of the oasis of Balad Seet for their patience and hospitality.

\section{References}

Al-Maskri, M., Nagieb, M., Hammer, K., Filatenko, A.A., Khan, I., Buerkert, A., 2003. A note about Triticum in Oman. Gen. Res. Crop. Evol. 50, 83-87.
Ayers, R.S., Westcot, D.W., 1994. Water Quality for Agriculture. Irrig. and Drain. Paper No. 29, Rev. 1. FAO, Rome, Italy.

Brooks, S.C., Taylor, D.L., Jardine, P.M., 1998. Thermodynamics of bromide exchange on ferrihydrite: implications for bromide transport. Soil Sci. Soc. Am. J. 62, 1275-1279.

Buerkert, A., Nagieb, M., Siebert, S., Al-Maskri, A., Khan, I., 2005. Nutrient cycling and field-based partial nutrient balances in two mountain oases of Oman. Field Crops Res. (accepted).

Campbell, C.S., 2002. Response of ECH2O Soil Moisture Sensor to Temperature Variation. Application Note. Decagon Devices, Pullman, WA, USA.

Chanzy, A., Chadoeuf, J., Gaudu, J.C., Mohrath, D., Richard, G., Bruckler, L., 1998. Soil moisture monitoring at the field scale using automatic capacitance probes. Eur. J. Soil Sci. 49, 637-648.

Dixon, W.J., 1950. Ratios involving extreme values. Ann. Math. Stat. 21, 488-506.

Dorvlo, A.S.S., Ampratwum, D.B., 1998. Summary climatic data for solar technology development in Oman. Renew. Energy 1, $255-262$.

Dorvlo, A.S.S., Ampratwum, D.B., 1999. Modelling of weather data for Oman. Renew. Energy 17, 421-428.

FAO, 1997. FAOSTAT Agriculture Database. FAO, Rome, Italy. Accessible at: http://www.fao.org.

FAO, 2001. Lecture Notes on the Major Soils of the World. FAO, Rome, Italy.

Fares, A., Alva, A.K., 2000. Evaluation of capacitance probes for optimal irrigation of citrus through soil moisture monitoring in an entisol profile. Irrig. Sci. 19, 57-64.

Flury, M., 1993. Transport of bromide and chloride in a sandy and a loamy soil. PhD Dissertation No 10185, Eidgenössische Technische Hochschule (ETH), Zürich, Switzerland.

Gee, G.W., Bauder, J.W., 1986. Particle size analysis. In: Klute, A. (Ed.), Methods of Soil Analysis: Part 1. Physical and Mineralogical Methods, 2nd ed. Agron. Monogr. vol. 9. ASA and SSSA, Madison, WI.

Hartge, K.H., 1966. Ein Haubenpermeameter zum schnellen Durchmessen zahlreicher Stechzylinderproben. Z. Kulturtech. Flurbereinig. 7, 155-163.

Hoffman, G.J., Durnford, D.S., 1999. Drainage design for salinity control. Chap. 17. Skaggs, R.W., Van Schilfgaarde, J. (Eds.), Agricultural Drainage, Agronomy Series, vol. 38. American Society of Agronomy, Madison, USA.

Jorenush, M.H., Sepaskhah, A.R., 2003. Modelling capillary rise and soil salinity for shallow saline water table under irrigated and non-irrigated conditions. Agric. Water Manag. 61, 125-141.

Khosla, R., Persaud, N., 1997. Performance of a non-nuclear resonant frequency capacitance probe: 1 . Calibration and field testing. Commun. Soil Sci. Plant Anal. 28, 1333-1345.

Lado, M., Paz, A., Ben-Hur, M., 2004. Organic matter and aggregate-size interactions in saturated hydraulic conductivity. Soil Sci. Soc. Am. J. 68, 234-242.

Lane, P.N.J., Mackenzie, D.H., 2001. Field and laboratory calibration and test of TDR and capacitance techniques for indirect measurement of soil water content. Aust. J. Soil Res. 39, $1371-1386$ 
Maas, E.V., Hoffmann, G.J., 1977. Crop salt tolerance-current assessment. ASCE J. Irrig. Drain. Div. 103 (IR2), 115-134.

Mead, R.M., Ayars, J.E., Liu, J., 1995. Evaluating the influence of soil texture, bulk density and soil water salinity on a capacitance probe calibration. ASAE Summer Meeting Presentation, Chicago, IL, USA, 1995.

Nagieb, M., Häser, J., Siebert, S., Luedeling, E., Buerkert, A., 2004. Settlement history of a mountain oasis in northern Oman-evidence from land use and archaeological studies. Erde (in press).

Norman, W.R., Shayya, W.H., Al-Ghafri, A.S., McCann, I.R., 1998. Aflaj irrigation and on-farm water management in northern Oman. Irrig. Drain. Sys. 12, 35-48.

Porro, I., Wierenga, P.J., Hills, R.G., 1993. Solute transport through large uniform and layered soil columns. Water Resour. Res. 29, $1321-1330$

Rhoades, J.D., 1982. Reclamation and management of salt-affected soils after drainage. Proc. First Annual Western Provincial Conf. Rationalization of Water and Soil Resources and Management, Lethbridge, Alberta, Canada. 29 November-2 December 1982, pp. $123-197$.

Rhoades, J.D., Kandiah, A., Mashali, A.M., 1992. The Use of Saline Waters for crop Production-FAO Irrigation and Drain- age Paper 48. Food and Agriculture Organization of the United Nations, Rome.

United States Salinity Laboratory Staff, 1954. Diagnosis and Improvement of Saline and Alkali Soils. Agricultural Handbook, vol. 60. United States Department of Agriculture, Washington, DC, USA.

Victor, R., Al-Farsi, A.A.I., 2001. Water quality and invertebrate fauna of farm wells in an area affected by salinization in Oman. J. Arid Environ. 48, 419-428.

Wichern, F., Luedeling, E., Müller, T., Joergensen, R.G., Buerkert, A., 2004a. Field measurements of the $\mathrm{CO}_{2}$ evolution rate under different crops during an irrigation cycle in a mountain oasis of Oman. Appl. Soil Ecol. 25, 85-91.

Wichern, F., Müller, T., Joergensen, R.G., Buerkert, A., 2004b. Effects of manure quality and application forms on soil $\mathrm{C}$ and $\mathrm{N}$ turnover of a subtropical oasis soil under laboratory conditions. Biol. Fertil. Soils 39, 165-171.

Wilkinson, J.C., 1977. Water and Tribal Settlement in South-East Arabia. A Study of the Aflaj of Oman. Oxford University Press, Oxford, UK.

Wu, K.G., 1998. Measurement of soil moisture change in spatially heterogeneous weathered soils using a capacitance probe. Hydrol. Process. 12, 135-146. 